\title{
Anionic cascade reactions. One-pot assembly of (Z)-chloro-exo-methylenetetrahydrofurans from $\beta$-hydroxyketones
}

\author{
István E. Markó* and Florian T. Schevenels
}

\section{Full Research Paper}

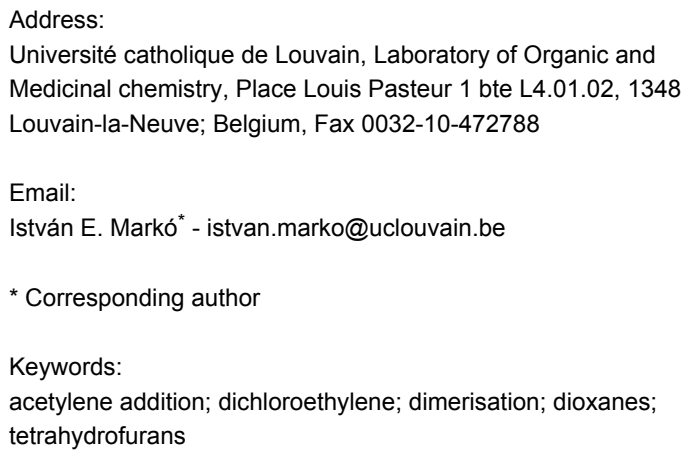

Université catholique de Louvain, Laboratory of Organic and Medicinal chemistry, Place Louis Pasteur 1 bte L4.01.02, 1348 Louvain-la-Neuve; Belgium, Fax 0032-10-472788

Email:

István E. Markó* - istvan.marko@uclouvain.be

* Corresponding author

Keywords:

acetylene addition; dichloroethylene; dimerisation; dioxanes; tetrahydrofurans

\section{Open Access}

Beilstein J. Org. Chem. 2013, 9, 1319-1325.

doi:10.3762/bjoc. 9.148

Received: 08 April 2013

Accepted: 12 June 2013

Published: 03 July 2013

This article is part of the Thematic Series "Creating complexity".

Guest Editor: D. Craig

C 2013 Markó and Schevenels; licensee Beilstein-Institut. License and terms: see end of document.

\begin{abstract}
The assembly of $(Z)$-chloro-exo-methylenetetrahydrofurans by an original and connective anionic cascade sequence is reported. Base-catalysed condensation of $\beta$-hydroxyketones with 1,1-dichloroethylene generates, in moderate to good yields, the corresponding (Z)-chloro-exo-methylenetetrahydrofurans. Acidic treatment of this motif leads to several unexpected dimers, possessing unique structural features.
\end{abstract}

\section{Introduction}

Recently, we have shown that simple ketones reacted with 1,1-dichloroethylene, in the presence of potassium tertbutoxide, to afford rare (Z)-chloro-exo-methyleneketals [1-3]. This unique transformation is particularly efficient in the case of six-membered ring ketones (Scheme 1). In an attempt to extend the scope of this cascade process to acyclic ketones, acetone was submitted to the usual reaction conditions. To our surprise, the expected adduct $\mathbf{5}$ was formed in only poor yields. The major product was isolated in $36 \%$ yield and its structure was unambiguously determined as the ( $Z$ )-chloro-exomethylenetetrahydrofuran 6 .

The generation of 6 can be rationalized as depicted in Scheme 2. Under the basic conditions employed for the cascade

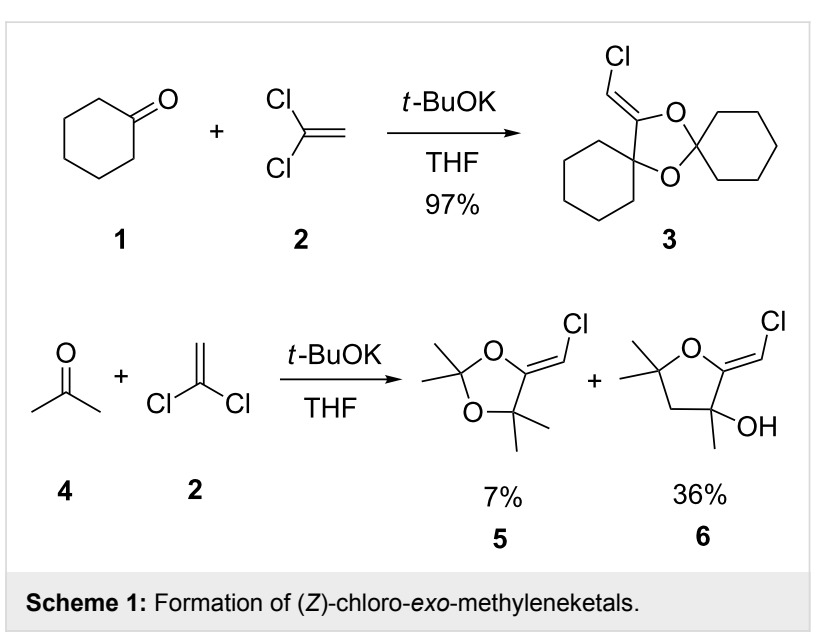



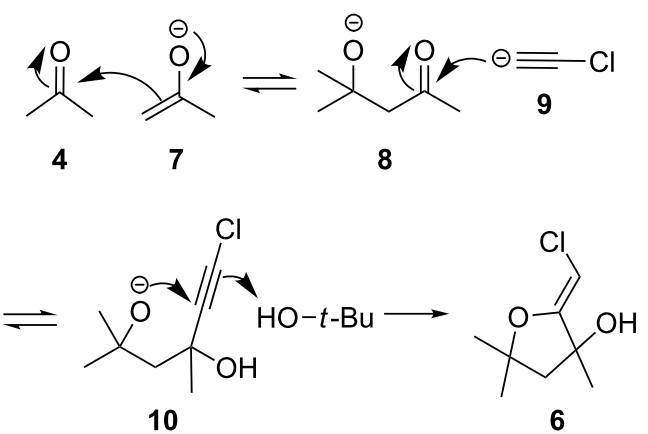

Scheme 2: Mechanism of formation of (Z)-chloro-exo-methylenetetrahydrofurans.

reaction, 1,1-dichloroethylene is converted into the corresponding chloro-acetylene anion 9 [4,5]. This nucleophilic species adds rapidly, though reversibly, to acetone, leading ultimately to the formation of $\mathbf{5}$. However, in this case, competitive aldol reaction appears to take place, delivering the adduct 8 . The subsequent addition of $\mathbf{9}$ then affords the intermediate $\mathbf{1 0}$, which undergoes a 5-exo-dig cyclisation, ultimately yielding the observed (Z)-chloro-exo-methylenetetrahydrofuran 6.

This structural motif constitutes the core of several biologically active compounds, including antimicrobial agents, fungicides and interesting competitive inhibitors of $S$-adenosyl-L-homocysteine (AdoHcy) hydrolase, one of the target enzymes extensively studied in the context of antiviral chemotherapy [6-9]. Despite their utility, only a limited number of multistep methods have been described for the preparation of this subunit [10-16]. The paucity of efficient synthetic approaches towards this family of compounds and the desire to assess the scope and limitations of this method prompted us to further investigate this transformation.

\section{Results and Discussion}

When 4-hydroxy-2-butanone (11) was treated with lithium chloroacetylide, generated in situ from dichloroethylene and LDA, the diol 12 was obtained in 77\% yield. This adduct smoothly cyclized to $\mathbf{1 3}$ upon addition of sodium or potassium tert-butoxide, thereby supporting our mechanistic proposal. Repeating the process without isolation of the intermediate diol 12 proved to be even more efficient, affording the $(Z)$-chloroexo-methylenetetrahydrofuran 13 in $66 \%$ overall yield (Scheme 3).

It is interesting to note that, in the case of the substrate 11, the adduct $\mathbf{1 3}$ could be isolated in an improved $81 \%$ yield when potassium tert-butoxide was employed as the sole base (Scheme 4). In stark contrast, applying this procedure to the keto-alcohol 14 resulted in a mediocre $13 \%$ yield of 6 , prob-



Scheme 3: Stepwise formation of (Z)-chloro-exo-methylenetetrahydrofurans.
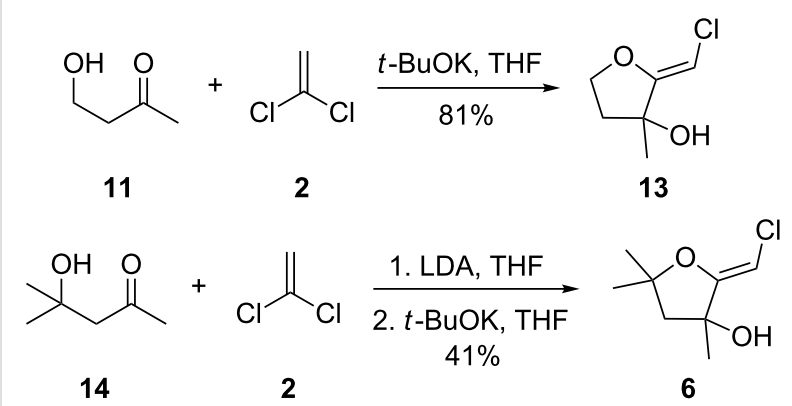

Scheme 4: Optimized protocols to form (Z)-chloro-exo-methylenetetrahydrofurans.

ably due to a rapid retro-aldol reaction of the derived, rather hindered, potassium alkoxide. Applying the LDA/KO $t$-Bu protocol improved the yield to $41 \%$.

It thus transpires that good to excellent yields of $(Z)$-chloro-exomethylenetetrahydrofurans could be obtained by the judicious choice of the bases employed to promote this cascade process. Having delineated some suitable conditions, the scope and limitations of this methodology were investigated [17-27]. Some selected examples are collected in Table 1.

As can be seen from Table 1, the reaction proves to be quite general and high-yielding for several primary alcohols (Table 1, entries 2, 3, 7 and 8). The yield was somewhat lower for two of them (Table 1, entries 4 and 6) due to rapid retro-aldol reactions and to enhanced steric hindrance, respectively. In the case of tertiary alcohols, the reaction proceeded with acceptable yields, especially in view of the one-pot nature of our procedure (Table 1, entries 1 and 5). 
Having access to a broad range of substituted (Z)-chloro-exomethylenetetrahydrofurans, a brief survey of their reactivity was performed. Several reactions involving the vinyl chloride function proved unsuccessful $[28,29]$. Attempts to perform oxidative rearrangement and dehydration failed and functionalisation of the hydroxy group appeared difficult [30,31]. Initially, the adduct 13 was treated with aqueous hydrochloric acid, in the hope of generating the corresponding dihydrofuran carbaldehyde 33. Instead, the diol $\mathbf{3 4}$ was obtained in $52 \%$ yield as a

Table 1: Preparation of (Z)-chloro-exo-methylenetetrahydrofurans<smiles>[R]C(=O)C([R1])(O)C([R])([R])O</smiles>

15<smiles>[R]C1([R])OC(=CCl)C([R])(O)C1([R])[R]</smiles>

16

\begin{tabular}{|c|c|c|c|}
\hline Entry & Substrate & Product & Yield $^{\mathrm{a}}$ \\
\hline
\end{tabular}

1<smiles>CCC(=O)CC(C)(C)O</smiles>

17<smiles>[R5]C1(CCl)CC(C)(C)OC1=CCl</smiles>

25

2<smiles>CCC(=O)CCO</smiles>

18<smiles>CCC1(O)CCOC1=CCl</smiles>

26

3<smiles>CC(C)C(=O)CCO</smiles>

19<smiles>OC1(C(F)(F)F)CCOC1=CCl</smiles>

27<smiles>O=C(CCO)c1ccccc1</smiles>

20<smiles>OC1(c2ccccc2)CCOC1=CCl</smiles>

28

5<smiles>CC(C)C(=O)CC(C)(C)O</smiles>

21<smiles>CC(C)C1(O)CC(C)(C)OC1=CCl</smiles>

29<smiles>CC(=O)C1(CO)CCCCC1</smiles>

22<smiles>CC1(O)C(=CCl)OCC12CCCCC2</smiles>

$39 \%$

$80 \%{ }^{c}$

$73 \%$ c

$38 \% c$ $47 \%$ b

$40 \%$ b

$42 \%$ c
Table 1: Preparation of (Z)-chloro-exo-methylenetetrahydrofurans. (continued)
7<smiles>CC(=O)C(C)(C)CO</smiles>

23<smiles>C=C(CO)C(C)=O</smiles>

24<smiles>CC1(C)CO/C(=C\Cl)C1(C)O</smiles>

31

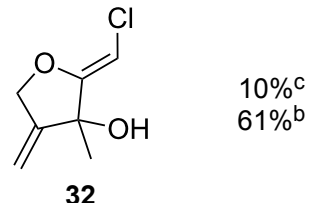

aAll yields are for pure, isolated products. ${ }^{b}$ In these cases, 2.2 equiv of $\mathrm{C}_{2} \mathrm{H}_{2} \mathrm{Cl}_{2}$ and 4.4 equiv of LDA were used in the first step, followed by 1 equiv of $t$-BuOK in the second step. 'For these substrates, 2.5 equiv of $\mathrm{C}_{2} \mathrm{H}_{2} \mathrm{Cl}_{2}$ and 5 equiv of $t$-BuOK were used to generate the acetylide.

1:1 mixture of diastereoisomers. It thus transpires that protonation and hydration of the exo-methylene double bond of $\mathbf{1 3}$ proceeded faster than the expected rearrangement of the tertiary allylic alcohol (Scheme 5).

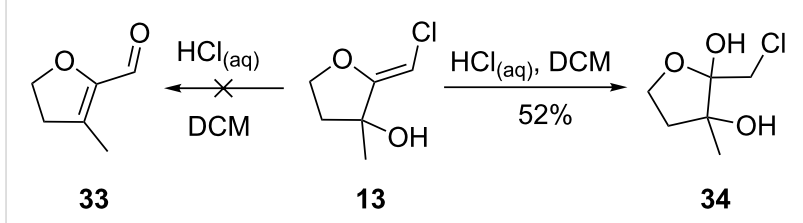

Scheme 5: Hydration of (Z)-chloro-exo-methylenetetrahydrofurans.

To promote such an acid-catalyzed rearrangement, the (Z)-chloro-exo-methylenetetrahydrofuran $\mathbf{1 3}$ was treated with a catalytic amount of para-toluenesulfonic acid. To our surprise, the anti-dioxane $\mathbf{3 5}$ and its syn-derivative $\mathbf{3 6}$ were obtained as a 1:5 mixture of diastereoisomers that could be separated (Scheme 6). Their structure was unambiguously established by single-crystal X-ray diffraction analysis, as shown in Figure 1. Increasing the steric hindrance at the tertiary alcohol site resulted in the exclusive formation of the syn-dioxanes $\mathbf{3 7}$ and 38 respectively, albeit at the expense of the yield [32-38].

When the dimethyl adduct 6 was submitted to the same conditions, a new product [39-45] $\mathbf{4 1}$ was formed besides the dioxanes 39 and 40 (Scheme 7). Its structure was unambiguously established as the spirocyclic dimer $\mathbf{4 1}$ by single-crystal X-ray diffraction analysis. It is noteworthy that a single diastereoisomer was generated in this transformation.

The formation of these unique compounds can be rationalized as depicted in Scheme 8 . Under acidic conditions, the 


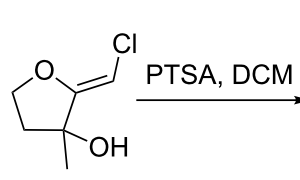

13

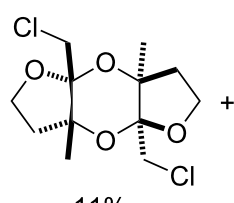

35

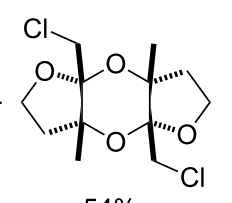

36

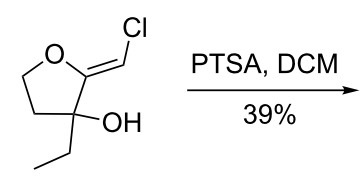

26

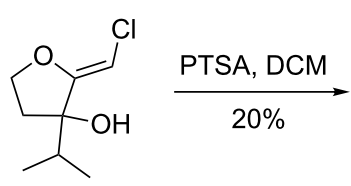

27

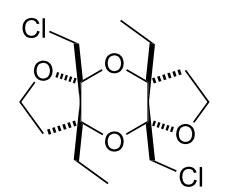

37

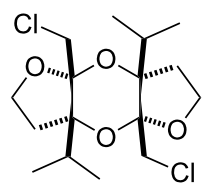

38
Scheme 6: Formation of dioxanes.
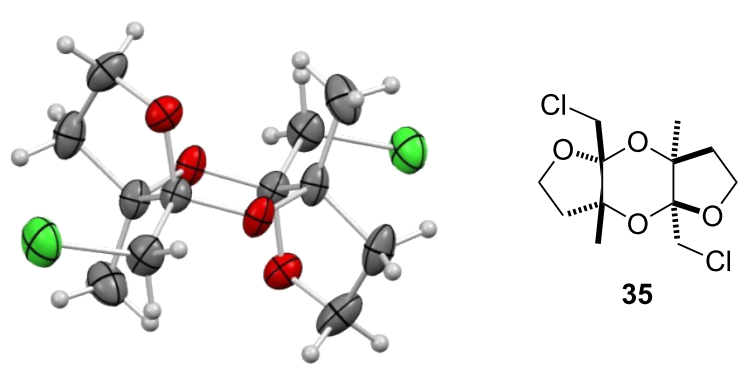

35
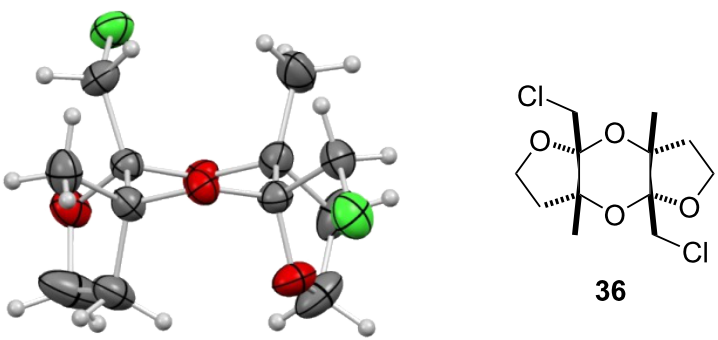

36

Figure 1: X-ray diffraction analysis of dioxanes 35 and 36

(Z)-chloro-exo-methylenetetrahydrofuran $\mathbf{4 2}$ is converted into the oxonium cation 43. Subsequent capture of this intermediate $\mathbf{4 3}$ by a second molecule of $\mathbf{4 2}$ can occur via two different pathways. The first one involves the addition of the enol ether function of 42 onto 43 , leading to the creation of a new $\mathrm{C}-\mathrm{C}$ bond with concomitant generation of another oxonium species 47 . Intramolecular capture of this electrophile by the pendant hydroxy substituent then delivers the spirocyclic adduct $\mathbf{4 8}$. Alternatively, reaction of the tertiary alcohol of $\mathbf{4 2}$ with the oxonium cation $\mathbf{4 3}$ affords the ketal 44. Protonation of the enol

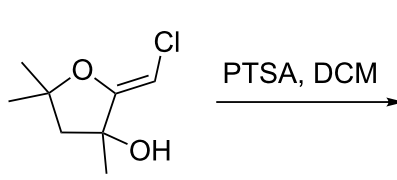

6<smiles>CC1(C)C[C@]2(C)O[C@]3(CCl)CC(C)(C)O[C@@]3(CCl)O[C@]2(C)C1</smiles>

$5 \%$

39<smiles>CC1(C)C[C@]2(C)O[C@]3(CCl)OC(C)(C)C[C@]3(C)O[C@]2(CCl)O1</smiles>

$44 \%$<smiles>CC1(C)C[C@@](C)(O)C2(O1)O[C@@]1(C)CC(C)(C)O[C@@]1(CCl)[C@H]2Cl</smiles>

$17 \%$

41
Scheme 7: Formation of a new spirocyclic dimer.

ether function, followed by 6-exo-trig cyclization, completes this sequence of events and provides the dioxane derivative $\mathbf{4 6}$. Interestingly, no reaction was observed when the spirocycle $\mathbf{4 1}$ and the dioxanes $\mathbf{3 5}, \mathbf{3 6}$ and $\mathbf{3 9}$ were reacted under acidic conditions, indicating that the final step is not reversible.

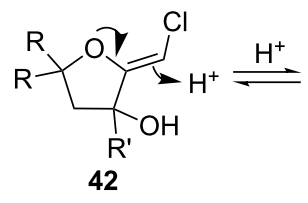

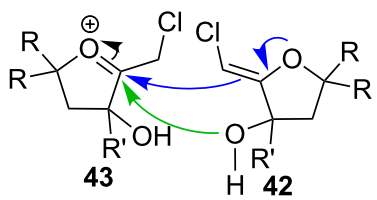<smiles>[R]C1([R])CC([R])(OC2([R])CC([R])([R])C([R])(OC3([R])CC([R])([R])OC3([R])O)C2(O)CCl)C(=CCl)O1</smiles>

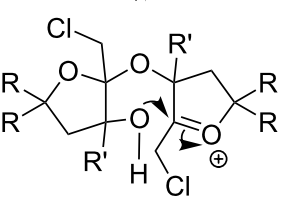

45<smiles>[R]C1([R])CC2(O)C([R])([R])CC3([R])OC([R])(CCl)OC3(CCl)OC2(CCl)O1</smiles><smiles>[R]C1([R])CC2([R])OC3(OC([R])([R])CC3([R])O)C(Cl)C2(CCl)O1</smiles>

Scheme 8: Mechanism leading to dioxanes and spirocycles. 
It is noteworthy that the dioxanes possess predominantly (13) or exclusively (26 and 27) the syn-syn relative stereochemistry at the ring junctions. This selectivity can be rationalized by an initial addition of the nucleophile syn to the alcohol function, as shown in Scheme 9. Interestingly, the homochiral $(S, S ; R, R)$ dimer, leading to the $s y n-s y n$ product, is preferred over the heterochiral $(S, R ; R, S)$-adduct, affording the syn-anti isomer. Increasing the steric hindrance at the tertiary alcohol center of 49 leads to prohibitive steric repulsion during the heterodimer formation. A similar facial selectivity can explain the formation of $\mathbf{4 1}$ as a single diastereoisomer.
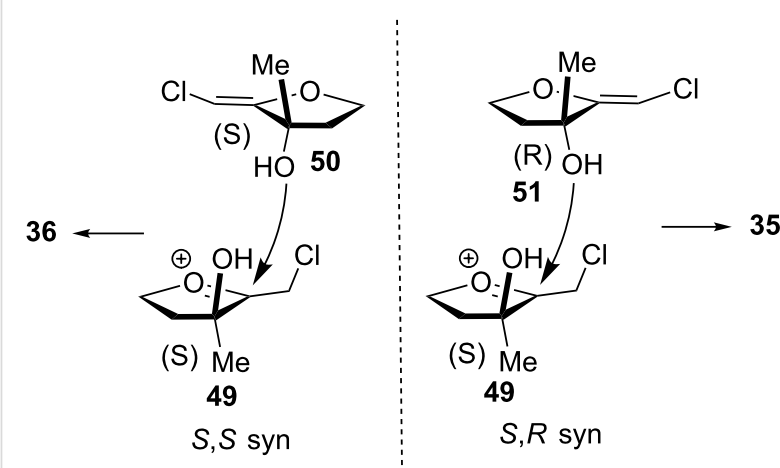

Scheme 9: (S,S)-syn and $(S, R)$-syn approaches.

When the adduct $\mathbf{2 5}$, bearing a gem-dimethyl substituent was submitted to this transformation, no dioxane was observed. The major product proved to be the spirocyclic adduct $\mathbf{5 3}$, accompanied by the bridged bis-ketal 52, in $41 \%$ and $13 \%$ yield respectively (Scheme 10). Treatment of the isopropyl derivative 29 under the same acidic conditions provided the triene $\mathbf{5 4}$ in $\mathbf{5 7 \%}$ yield. Addition of aqueous $\mathrm{HCl}$ generated the hemi-ketal $\mathbf{5 5}$ in $43 \%$ yield. The starting material was recovered in $52 \%$ yield.

The structures of compounds $\mathbf{5 3}$ and $\mathbf{5 5}$ were unambiguously established by single-crystal X-ray diffraction analysis (Figure 2).

Once again, increasing the steric effect around the tertiary alcohol function of the $(Z)$-chloro-exo-methylenetetrahydrofurans has a profound influence on the fate of the condensation reaction. A plausible mechanistic rationale is provided in Scheme 11.

In the presence of the gem-dimethyl substituent, dehydration of 42 to afford 56 appears to proceed rapidly, probably owing to a release of steric strain. The loss of water occurs especially readily when $\mathrm{R}^{\prime}=\mathrm{Et}$ or $\mathrm{iPr}$ and to a lesser extent when $\mathrm{R}^{\prime}=\mathrm{Me}$, indicating that steric decompression may indeed be operational in these cases. Protonation of diene $\mathbf{5 6}$ leads to the
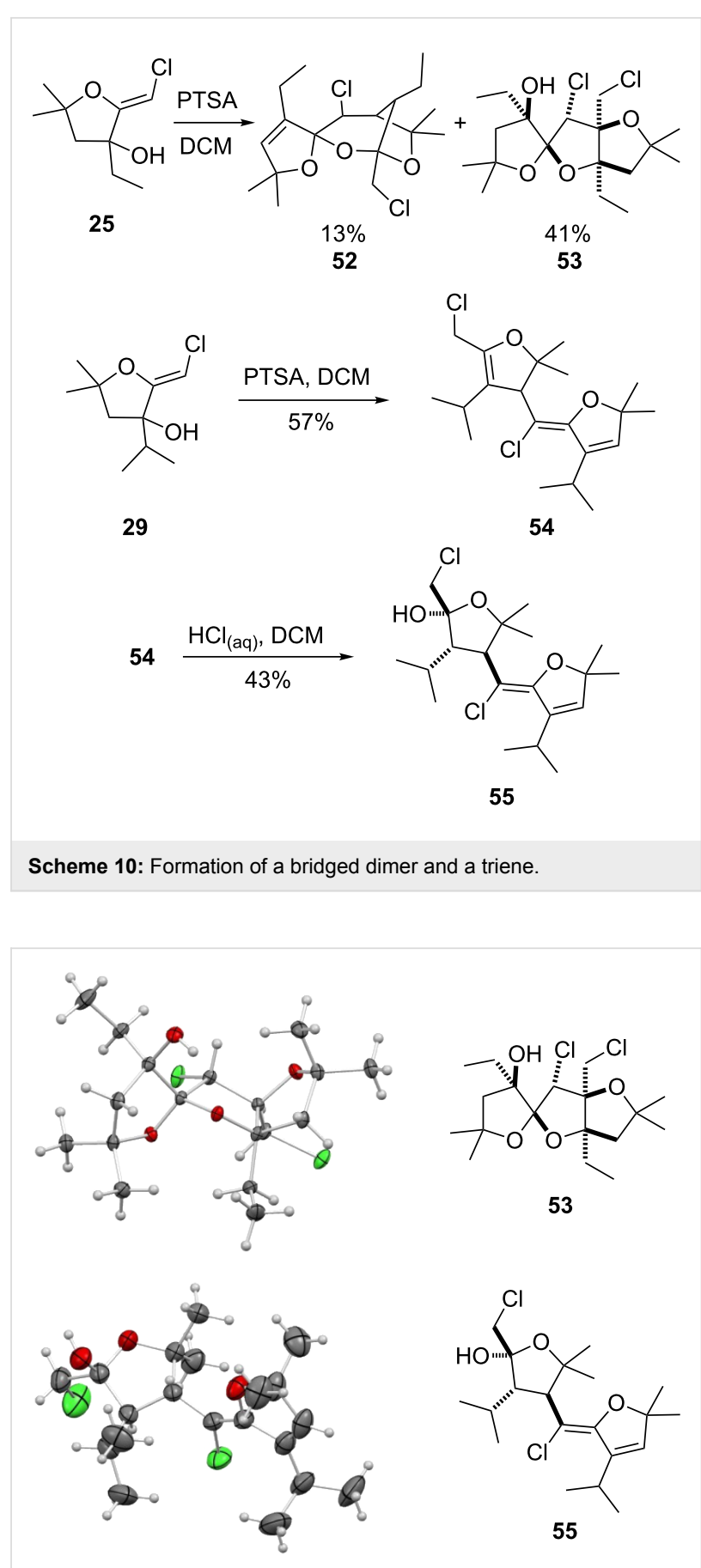

Figure 2: X-ray diffraction analysis of two new dimers.

oxonium ion 57, which undergoes a 1,4-addition of another 56 unit, affording the new cation 58. At this stage, two different pathways can be followed. Either carbocation $\mathbf{5 8}$ can lose a proton, generating the observed triene $\mathbf{5 9}$, or it may undergo addition of a water molecule, affording the hemiketal $\mathbf{6 0}$. Addition of a proton to the vinyl ether function, followed by intramolecular capture by the hydroxy group, finally provides the unique bridged adduct $\mathbf{6 2}$. 

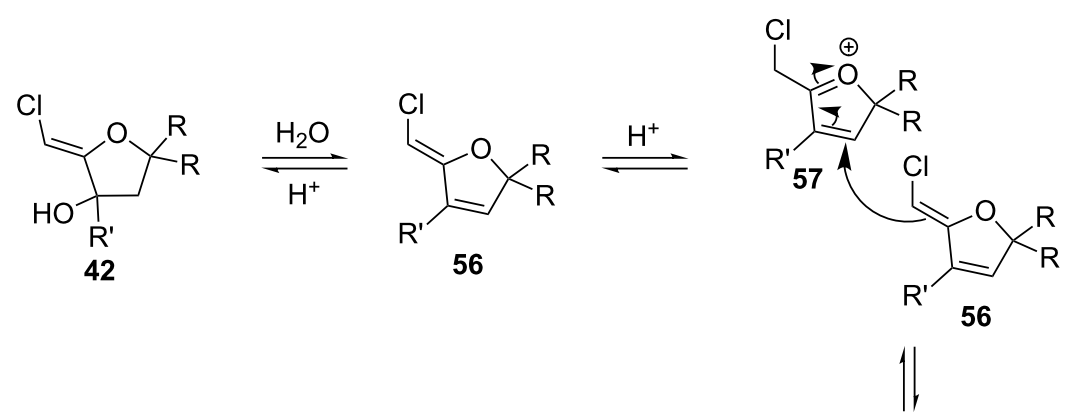<smiles>[R]C1=CC([R])([R])OC1=C(Cl)C1C([R])=C(CCl)OC1([R])[R]</smiles>

59<smiles>[R]C1=CC([R])([R])O[R]([H])([H])[C@H]1[C@H](Cl)C1([R])OC([R])=C(CCl)C1[R]</smiles>

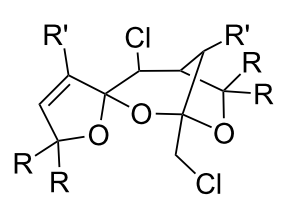

62<smiles>C[In]C1CC1</smiles>

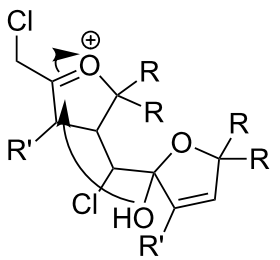

61<smiles>CC1CC1CC1CC1</smiles>

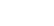

58<smiles>C=CO</smiles>

$\mathrm{R}=\mathrm{Me}, \mathrm{R}^{\prime}=\mathrm{Et}, \mathrm{iPr}$

Scheme 11: Mechanism leading to bridged and dienic dimers.

\section{Conclusion}

In summary, a unique anionic cascade process, leading to the efficient and connective assembly of ( $Z$ )-chloro-exo-methylenetetrahydrofurans from $\beta$-hydroxyketones, has been uncovered and developed. The reactivity of this unusual motif has been briefly investigated, and dimers, possessing rather unusual structures, have been obtained. It is noteworthy that some of these dimeric products form the core of interesting biologically active compounds and of unique natural products.

\section{Experimental}

\section{General procedure for the synthesis of chloromethylenefurans}

To $40 \mathrm{~mL}$ of anhydrous $\mathrm{THF}$, cooled to $0{ }^{\circ} \mathrm{C}, 1.2 \mathrm{~mL}$ (15.0 mmol, 2.5 equiv) of dichloroethylene and $3.37 \mathrm{~g}$ of potassium tert-butoxide were added. After 15 minutes, $700 \mathrm{mg}$ (6.0 mmol, 1 equiv) of hydroxyketone in $1 \mathrm{~mL}$ of THF were added. After one hour, $20 \mathrm{~mL}$ of water was added and the mixture was neutralized with diluted sulfuric acid. The aqueous layer was extracted with $2 \times 20 \mathrm{~mL}$ of DCM. The organic layer was dried, filtered and concentrated. The crude product was further purified by chromatography over silica gel providing $820 \mathrm{mg}$ (4.6 mmol, 77\%) of chloromethylenefuran $\mathbf{3 1}$ as a white solid. For full details, see Supporting Information File 1.

\section{Supporting Information}

\section{Supporting Information File 1}

Experimental procedures and analytical data of cited compounds.

[http://www.beilstein-journals.org/bjoc/content/ supplementary/1860-5397-9-148-S1.pdf]

\section{Acknowledgements}

Financial support by the Université catholique de Louvain (UCL), the Fonds pour la formation à la Recherche dans l'Industrie et dans l'Agriculture (F.R.I.A.) and the Action de Recherches Concertées (ARC 08/13-012) is gratefully acknowledged. 


\section{References}

1. Schevenels, F.; Markó, I. E. Chem. Commun. 2011, 47, 3287. doi:10.1039/c0cc05186a

2. Schevenels, F.; Markó, I. E. Org. Lett. 2012, 14, 1298 doi:10.1021/ol300186s

3. Schevenels, F.; Tinant, B.; Declercq, J.-P.; Markó, I. E. Chem.-Eur. J. 2013, 19, 4335. doi:10.1002/chem.201201505

4. Viehe, H. G. Chem. Ber. 1959, 92, 1270. doi:10.1002/cber.19590920607

5. Kloster-Jenson, E. Tetrahedron 1971, 27, 33. doi:10.1016/S0040-4020(01)92395-6

6. Prakash, N. J.; Davis, G. F.; Jarvi, E. T.; Edwards, M. L.; McCarthy, J. R.; Bowlin, T. L. Life Sci. 1992, 50, 1425. doi:10.1016/0024-3205(92)90261-M

7. Buchecker, R.; Fuenfschilling, J.; Marck, G. Mol. Cryst. Liq. Cryst. Sci. Technol., Sect. A 1997, 302, 295. doi:10.1080/10587259708041840

8. Kumamoto, H.; Onuma, S.; Tanaka, H.; Kitade, Y. Nucleic Acids Symp. Ser. 2003, 3, 13. doi:10.1093/nass/3.1.13

9. Jarvi, E. T.; McCarthy, J. R.; Mehdi, S.; Matthews, D. P.; Edwards, M. L.; Prakash, N. J.; Bowlin, T. L.; Sunkara, P. S.; Bey, P. J. Med. Chem. 1991, 34, 647. doi:10.1021/jm00106a028

10. Kumamoto, H.; Onuma, S.; Tanaka, H. J. Org. Chem. 2004, 69, 72. doi:10.1021/jo030256y

11. Wnuk, S. F.; Dalley, N. K.; Robins, M. J. J. Org. Chem. 1993, 58, 111. doi:10.1021/jo00053a022

12. Xu, M.; Miao, Z.; Bernet, B.; Vasella, A. Helv. Chim. Acta 2005, 88, 2918. doi:10.1002/hlca.200590235

13. Csuk, R.; Glänzer, B. Tetrahedron 1991, 47, 1655. doi:10.1016/S0040-4020(01)96909-1

14. Gómez, A. M.; Danelón, G. O.; Pedregosa, A.; Valverde, S.; López, J. C. Chem. Commun. 2002, 2024. doi:10.1039/b205121d

15. Blandino, M.; McNelis, E. Org. Lett. 2002, 4, 3387. doi:10.1021/ol026422q

16. Craig, G. W.; Sternberg, E. D.; Jones, G. H.; Moffatt, J. G. J. Org. Chem. 1986, 51, 1258. doi:10.1021/jo00358a017

17. Wasserman, H. H.; Hearn, M. J.; Cochoy, R. E. J. Org. Chem. 1980, 45, 2874. doi:10.1021/jo01302a023

18. Hitchcock, S. R.; Perron, F.; Martin, V. A.; Albizati, K. F. Synthesis 1990, 1059. doi:10.1055/s-1990-27093

19. Einhorn, J.; Soulier, J.-L.; Bacquet, C.; Lelandais, D. Can. J. Chem. 1983, 61, 584. doi:10.1139/v83-104

20. Ueki, T.; Doe, M.; Morimoto, Y.; Kinoshita, T.; Tanaka, R.; Yoshihara, K. J. Heterocycl. Chem. 2001, 38, 165. doi:10.1002/jhet.5570380124

21. O’Neil, G. W.; Miller, M. M.; Carter, K. P. Org. Lett. 2010, 12, 5350 doi:10.1021/ol1024635

22. Kim, K. S.; Song, Y. H.; Lee, N. H.; Hahn, C. S. Tetrahedron Lett. 1986 27, 2875. doi:10.1016/S0040-4039(00)84667-5

23. Schneider, C.; Hansch, M.; Weide, T. Chem.-Eur. J. 2006, 11, 3010. doi:10.1002/chem.200400951

24. Lin, K.-W.; Tsai, C.-H.; Hsieh, I.-L.; Yan, T.-H. Org. Lett. 2008, 10, 1927. doi:10.1021/ol8004326

25. Sulmon, P.; De Kimpe, N.; Schamp, N. Org. Prep. Proced. Int. 1989, 21, 91. doi:10.1080/00304948909356351

26. Trost, B. M.; Yang, H.; Thiel, O. R.; Frontier, A. J.; Brindle, C. S. J. Am. Chem. Soc. 2007, 129, 2206. doi:10.1021/ja067305j

27. Gerwick, B. C., III; Fields, S. C.; Graupner, P. R.; Schmitzer, P. R.; Brewster, W. K. Methylidene Mevalonates and their Use as Herbicides. U.S. Patent CA2527439A1, May 19, 2006.
28. Scheiper, B.; Bonnekessel, M.; Krause, H.; Fürstner, A. J. Org. Chem. 2004, 69, 3943. doi:10.1021/jo0498866

29. Qing, F.-L.; Wang, R.; Li, B.; Zheng, X.; Meng, W.-D. J. Fluorine Chem. 2003, 120, 21. doi:10.1016/S0022-1139(02)00279-8

30. Dauben, W. G.; Michno, D. M. J. Org. Chem. 1977, 42, 682. doi:10.1021/jo00424a023

31. Ishihara, K.; Kubota, M.; Kurihara, H.; Yamamoto, H. J. Am. Chem. Soc. 1995, 117, 4413. doi:10.1021/ja00120a030

32. Yates, P.; Burke, P. M. Can. J. Chem. 1987, 65, 1695. doi:10.1139/v87-284

33. Martin, O. R.; Rao, S. P.; Hendricks, C. A. V.; Mahnken, R. E. Carbohydr. Res. 1990, 202, 49. doi:10.1016/0008-6215(90)84070-B

34. Adam, W.; Peters, C.; Sauter, M. Synthesis 1994, 111. doi:10.1055/s-1994-25416

35. Dawid, M.; Warkentin, J. Can. J. Chem. 2003, 81, 598. doi:10.1139/v02-200

36. Timmer, M. S. M.; Stocker, B. L.; Seeberger, P. H. J. Org. Chem. 2006 71, 8294. doi:10.1021/jo061607m

37. Mukherjee, S.; Roy, B. G.; Das, S. N.; Mandal, S. B. Tetrahedron Lett. 2012, 53, 4929. doi:10.1016/j.tetlet.2012.06.121

38. Ting, C.-M.; Wang, C.-D.; Chaudhuri, R.; Liu, R.-S. Org. Lett. 2011, 13, 1702. doi: $10.1021 / \mathrm{ol} 2002144$

39. Chang, S.; Britton, R. Org. Lett. 2012, 14, 5844. doi:10.1021/ol302694s

40. Tlais, S. F.; Dudley, G. B. Beilstein J. Org. Chem. 2012, 8, 1287. doi:10.3762/bjoc.8.146

41. Brimble, M. A.; Finch, O. C.; Heapy, A. M.; Fraser, J. D.; Furkert, D. P.; O'Connor, P. D. Tetrahedron 2011, 67, 995. doi:10.1016/j.tet.2010.11.107

42. Tlais, S. F.; Dudley, G. B. Org. Lett. 2010, 12, 4698 doi:10.1021/ol102201z

43. Fernandes, R. A.; Ingle, A. B. Synlett 2010, 158. doi:10.1055/s-0029-1218538

44. Ramana, C. V.; Suryawanshi, S. B.; Gonnade, R. G. J. Org. Chem. 2009, 74, 2842. doi:10.1021/j0802539z

45. Seibert, S. F.; Krick, A.; Eguereva, E.; Kehraus, S.; Koenig, G. M. Org. Lett. 2007, 9, 239. doi:10.1021/010626802

\section{License and Terms}

This is an Open Access article under the terms of the Creative Commons Attribution License (http://creativecommons.org/licenses/by/2.0), which permits unrestricted use, distribution, and reproduction in any medium, provided the original work is properly cited.

The license is subject to the Beilstein Journal of Organic Chemistry terms and conditions: (http://www.beilstein-journals.org/bjoc)

The definitive version of this article is the electronic one which can be found at: doi: $10.3762 /$ bjoc. 9.148 